\title{
Oxygen fugacity of the metasomatizing melt in a polymict peridotite from Kimberley
}

\author{
Heidi E. Höfer, Marina Lazarov, Gerhard P. Brey, Alan B. Woodland \\ Institut für Geowissenschaften, Goethe-Universität, \\ Frankfurt am Main, Germany \\ hoefer@em.uni-frankfurt.de
}

\section{Introduction}

Kimberlites are highly Si-undersaturated and fluid charged melts which are not only the transport vehicles of diamonds and mantle material to the Earth's surface but, together with silicocarbonatitic melts, probably the most common media responsible for mantle metasomatism. To understand their chemical properties and reaction mechanisms with mantle material at depth, a further understanding of mantle metasomatism in general is required. With the detailed study of a very rare type of a brecciated xenolith, a so-called polymict peridotite, we are able to describe the interaction process of a percolating, Si-poor and Mg-rich, fluidcharged melt and determine the oxidation state of such melts.

Polymict peridotites were described first by Lawless et al. (1979) from the Kimberley pool, South Africa. They are mechanical mixtures of upper mantle clasts and minerals cemented by fine-grained olivine and minute amounts of interstitial picro-ilmenite, phlogopite, rutile and sulphide. Further work on these same samples by Zhang et al. (2000) lead to the interpretation that the breccias most likely represent tectonic rock units that were intermingled in mantle shear fault zones and solidified by an intruding melt. A large variation of oxygen isotope ratios and fractionation between and within the constituent minerals of these polymict xenoliths, led Zhang et al. (2000) to suggest that the melt interaction was arrested after entrainment and eruption into the kimberlite magma.

During a sampling campaign in 2002 on Boshof road dump in Kimberley we collected a further specimen of these polymict breccias which contained a vein with large Granny Smith clinopyroxenes and ilmenite set in a patchy matrix of greenish and brownish appearance. Its study enables us to put further constraints on explosive processes deep within the mantle, on the gas charged transport and turbulent mixing of solid mantle material and its halt and solidification as a rock by freezing out the mafic silicate portion of a highly gas charged kimberlitic melt.

\section{Petrography of the peridotite breccia}

Fig. 1 shows a polished slice of the polymict peridotite xenolith. Three zones are distinguishable: Part " $\mathrm{A}$ " is a section through the vein-like feature. It consists of large Granny Smith-clinopyroxene and ilmenite set in a fine grained matrix of reddish brown and light green patches made of fine grained garnet and orthopyroxene, resp. Granny Smith cpx is in a state of dissolution and in reaction with opx. The major parts B and $\mathrm{C}$, the polymict breccia itself, differ only in grain size. They consist of ol, opx, grt and very rare cpx clasts, randomly collected from peridotitic and rarely from eclogitic mantle lithologies, and amalgamated by a fine-grained olivine matrix which contains rare, up to $2 \mathrm{~mm}$ sized sulfides.

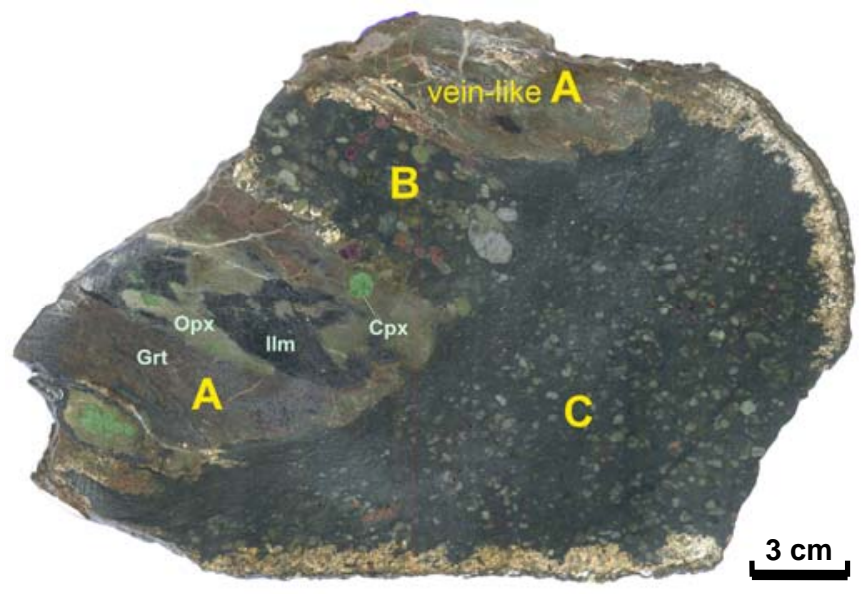

Fig. 1 Polished slice of polymict breccia Bosh03-79 collected from the Boshof Road dump, Kimberley, South Africa. The xenolith measures approximately 37 x $20 \times 16 \mathrm{~cm}$

The xenocrysts are homogeneous in their major and trace elements (Lazarov, PhD-Thesis 2008). Their outlines appear to reflect a state of dissolution (Fig. 2) after which polycrystalline overgrowth occurred of each individual mineral species, i.e. garnet on garnet, orthopyroxene on orthopyroxene and olivine on olivine except for clinopyroxene which is overgrown by orthopyroxene. Parts B and C seem to be intruded by A 
which we interpret as a solidifying magma with ilmenite and Granny Smith megacrysts and a residual melt which partly crystallized in situ to a Cr-poor, subcalcic garnet and orthopyroxene but also percolated the whole breccia. It reacted there with the constituent minerals whereby a Ca-richer (carbonatitic?) residual liquid left the whole system. The reaction of the melt in the breccia resulted in the mineral overgrowths whereby the grt and opx overgrowths are identical in composition to those in part A. It also led to the precipitation of the sulfides and the amalgamation by olivine.

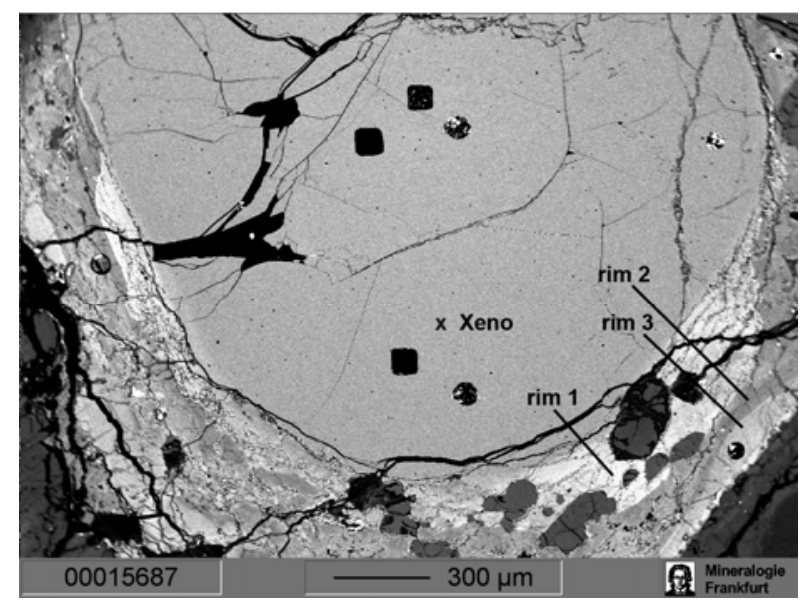

Fig. 2 Garnet Xenocryst with garnet overgrowth rims showing several laser ablation spots (BSE image). The position of the $\mathrm{Fe}^{3+} / \Sigma \mathrm{Fe}$ determination with the electron microprobe (flank method) is shown: one measuring spot within the xenocryst, three in different garnet overgrowth rims.

From contacting newly grown garnet and orthopyroxene pairs we estimate pressure temperature conditions for the solidification of about $3.5 \mathrm{GPa}$ and $1150^{\circ} \mathrm{C}$ (Opx-Grt barometer of Brey and Köhler, 1990 and Fe-Mg thermometer of Harley, 1984). This temperature is higher by about $150{ }^{\circ} \mathrm{C}$ than the surrounding mantle at that depth. This means that the formation of the polymict breccia was young and was probably related to the kimberlite magmatism itself. The peridotitic garnets give Ni-in-Grt temperatures between 1050 and $1300^{\circ} \mathrm{C}$ (Canil, 1999) which translates to a depth interval of around $70 \mathrm{~km}$ along a geotherm of $41 \mathrm{~mW} / \mathrm{m}^{2}$. Adding the $70 \mathrm{~km}$ onto the $115 \mathrm{~km}$ where solidification occurred means that the breccia collected rocks from depths of down to 185 $\mathrm{km}$.

\section{Analytical technique for in situ ferric iron} determination of small grains

So far, we determined the $\mathrm{Fe}^{2+} / \mathrm{Fe}^{3+}$ ratios in two garnet xenocrysts, a few newly grown garnet rims on xenocrysts in $\mathrm{B}$ and $\mathrm{C}$ and in garnets crystallized in the residual melt in part $\mathrm{A}$. We used the flank method as established by Höfer and Brey (2007) for determining the iron oxidation state with an electron microprobe. This method offers the advantage of the in situ determination of the ferric iron concentration at very high spatial resolution. In this study, the analytical conditions were chosen suitable for ferric iron determination in garnets with total Fe contents between 4.7 and 7.6 wt.-\%, i.e., $15 \mathrm{kV}, 200 \mathrm{nA}$, beam diameter $<1 \mu \mathrm{m}$, total analyzed area $12.5 \times 12.5 \mu^{2}$ with 25 repetitions within this area. Simultaneously to the flank measurements, a complete major-element analysis was carried out with an element calibration suitable for the high electron beam current. Creighton and Stachel (Univ. of Alberta, Canada) adopted our method and calibrated it especially for Cr-containing garnets (see extended abstract 9IKC). They had the $\mathrm{Fe}^{3+} / \Sigma \mathrm{Fe}$ in $\mathrm{Cr}-$ rich garnets from Diavik determined with the Mössbauer milliprobe by C. McCammon (Bayreuth, Germany) and used these as standards. We were supplied by Creighton and Stachel with aliquots of these garnets and used them as standards for our garnets in the polymict breccia which contain up to 4.6 wt.- $\% \mathrm{Cr}_{2} \mathrm{O}_{3}$. The comparison of our flank method determination of $\mathrm{Fe}^{3+} / \Sigma \mathrm{Fe}$ with Mössbauer yields an excellent agreement as shown in Fig. 3. The accuracy of the flank method ferric iron determination is comparable to Mössbauer spectroscopy.

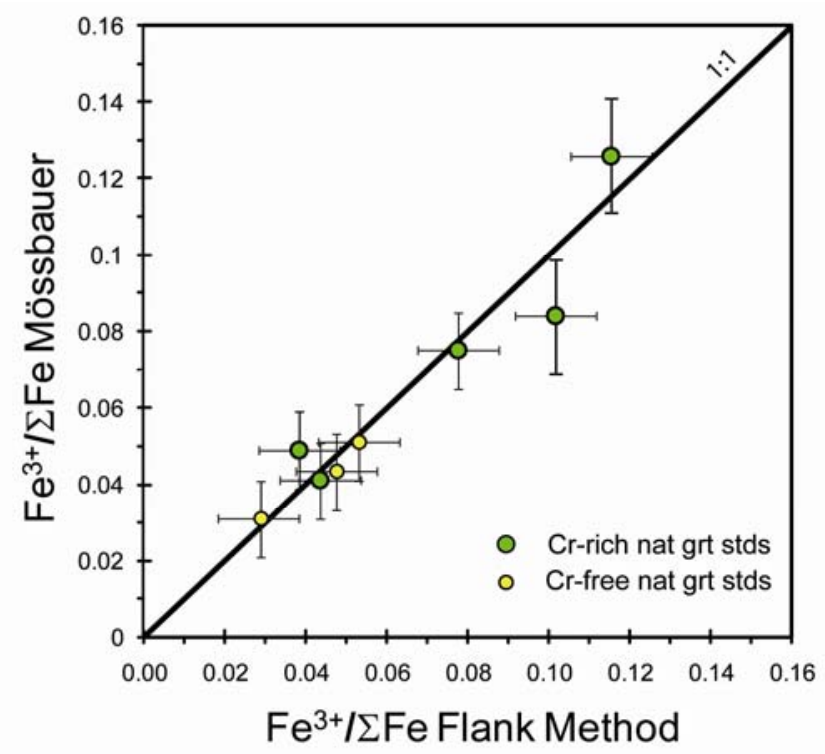

Fig. 3 Flank method versus Mössbauer milliprobe $\mathrm{Fe}^{3+} / \Sigma \mathrm{Fe}$ determination with $1 \sigma$ error bars. 


\section{Results and discussion}

From the $\mathrm{Fe}^{3+} / \Sigma \mathrm{Fe}$ ratios determined by EPMA the oxygen fugacity relative to FMQ was calculated for the conditions of solidification of the breccia (= partial crystallization of the melt) at $35 \mathrm{~kb}$ and $1150{ }^{\circ} \mathrm{C}$ by using the composition of the actual garnet and an average Mg\# of 90.5 and 90 for the newly grown orthopyroxenes and olivines resp. (after Gudmundsson and Wood, 1995; Table 1). The BSE image of xenocryst 1 in Fig. 2 shows the small areas where the microprobe $\mathrm{Fe}^{3+} / \Sigma \mathrm{Fe}$ determinations in the xenocryst and its overgrowth rims were carried out.

Table 1 Calculated $\Delta \log \mathrm{fO}_{2}$ values for part A garnets, $\mathrm{B}$ and $\mathrm{C}$ overgrowth rims $\left(1150{ }^{\circ} \mathrm{C}, 3.5 \mathrm{GPa}\right)$, for xenocryst $1\left(1050{ }^{\circ} \mathrm{C}, 4.8 \mathrm{GPa}\right)$ and xenocryst 2 (1150 $\left.{ }^{\circ} \mathrm{C}, 5.5 \mathrm{GPa}\right)$.

\begin{tabular}{|l|c|c|}
\hline Sample & $\mathbf{F e}^{\mathbf{3 +}} / \mathbf{\Sigma F e}$ & $\Delta \log \mathbf{f O}_{\mathbf{2}}$ \\
\hline Polymict breccia A & \multicolumn{3}{|l|}{} \\
\hline A gt2 core & 0.119 & -0.12 \\
\hline A gt2 1rim & 0.095 & -0.73 \\
\hline A gt2 2rim & 0.085 & -0.94 \\
\hline A gt3 core & 0.100 & -0.66 \\
\hline A gt3 rim & 0.077 & -1.17 \\
\hline A gt4 & 0.099 & -1.08 \\
\hline A gt 4rim & 0.108 & -1.22 \\
\hline A gt 5 & 0.117 & -0.25 \\
\hline Overgrowth rims & 0.092 & -1.16 \\
\hline B gt1 rim1 & 0.083 & -1.39 \\
\hline B gt1 rim2 & 0.079 & -1.23 \\
\hline B gt1 rim3 & 0.127 & -1.70 \\
\hline C gt1 rim1 & 0.093 & -1.57 \\
\hline C gt2 rim1 & 0.124 & -0.96 \\
\hline C gt2 rim2 & 0.127 & -0.73 \\
\hline C gt2 rim3 & 0.082 & -4.26 \\
\hline Xenocrysts & 0.115 & -4.18 \\
\hline B xenocryst 1 &
\end{tabular}

Figure 4 shows the calculated oxygen fugacities in comparison to the oxygen fugacities determined by Woodland and Koch (2003) for peridotite xenoliths from Kimberley. These authors found an increasing deviation of the oxygen fugacity from FMQ with depth i.e. the Kaapvaal mantle becomes more reducing with depth. The calculated oxygen fugacities for the newly grown garnets show a relatively large spread. The spread may be due to local modification of the chemistry due to reaction with the different mineral species and their differing compositions. They are, however, on average higher than the surrounding mantle (also at the higher temperature of crystallisation) i.e. the magma was more oxidizing than the surrounding mantle. The conditions also plot on the oxidizing side of the EMOG buffer, i.e., the metasomatising melt is probably a silico-carbonatitic melt and, because of the precipitation of olivine as the amalgamating phase, kimberlitic. If these more oxidizing conditions also prevailed in the magma at greater depths and if they are the transport vehicles for diamonds they would dissolve diamond during their uprise. This may be the reason for the huge quantity of diamonds with resorption morphology which are found in southern African diamond occurrences.

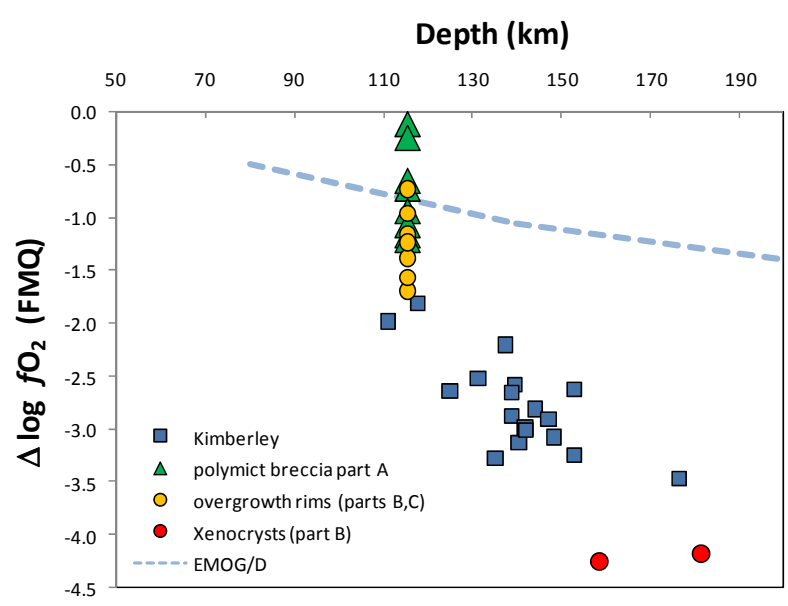

Fig. 4 Variation of $\Delta \log \mathrm{fO}_{2}$ with depth for xenoliths from Kimberley (Woodland \& Koch, 2003) and for a garnet xenocryst, garnet xenocryst overgrowth rims, and newly grown garnets in part $\mathrm{A}$ of the polymict breccia. The position of the EMOG/D buffer relative to FMQ is given for comparison.

\section{References}

Brey, G.P. and Köhler, T., 1990. Geothermobarometry in Four-phase Lherzolites II. New Thermobarometers, and practical assessment of existing thermobarometers. J. Petrology 31, part 6, 1353-1378.

Canil, D., 1999. The Ni-in-garnet geothermometer: calibration at natural abundances. Contributions Mineralogy Petrology 136, 240-246.

Gudmundsson, G., Wood, B.J., 1995. Experimental tests of garnet peridotite oxygen barometry. Contributions Mineralogy Petrology 119, 56-67.

Harley, S.L., 1984. Composition of the garnet-orthopyroxene geobarometer with recent experimental studies, and applications to natural assemblages. J. Petrology 25, 697-712.

Höfer, H.E., Brey G.P., 2007. The iron oxidation state of garnet by electron microprobe: Its determination with the flank method combined with major-element analysis. American Mineralogist, 92, 873-885.

Lawless, P.J., Gurney, J.J., Dawson, J.B., 1979. Polymict peridotites from the Bultfontein and De Beers mines, Kimberly, South Africa. The mantle sample: Inclusions in kimberlites and other volcanics. Proceedings of 2nd International Kimberlite Conference, 2, 145-155.

Lazarov, M., 2008. Archean to present day evolution of the lithospheric mantle beneath the Kaapvaal craton. PhDThesis, Frankfurt, Germany, 213 p.

Woodland, A.B., Koch, M., 2003. Variation in oxygen fugacity with depth in the upper mantle beneath the Kaapvaal craton, South Africa. Earth Planetary Science Letters 214, 295-310.

Zhang, H.F., Grassineau et al., 2000. Recent fluid processes in the Kaapvaal Craton, South Africa: coupled oxygen isotope and trace element disequilibrium in polymict peridotites. Earth Planetary Science Letters 176, 57-72. 